\title{
Clinical utility gene card for: Aarskog-Scott syndrome (faciogenital dysplasia)
}

\author{
Alfredo Orrico ${ }^{\star, 1,2}$, Lucia Galli ${ }^{1}$, Jill Clayton-Smith ${ }^{3}$, Jean-Pierre Fryns ${ }^{4}$ \\ European Journal of Human Genetics (2011) 19, doi:10.1038/ejhg.2011.108; published online 8 June 2011
}

\section{DISEASE CHARACTERISTICS}

1.1 Name of the disease (synonyms)

Aarskog-Scott syndrome (AAS), faciodigitogenital syndrome, FGDY, faciogenital dysplasia.

\subsection{OMIM\# of the disease}

305400 .

1.3 Name of the analysed genes or DNA/chromosome segments FGD1.

1.4 OMIM\# of the gene(s)

300546.

\subsection{Mutational spectrum}

Missense, nonsense, deletions and insertions are reported in addition to gross rearrangements. No mutational hotspots or common mutations are seen; the majority of mutations are unique within families. To the best of our knowledge, incorporating information from published articles, unpublished data and congress reports, 56 mutations have been characterised with the following mutational spectrum: 29 missense mutations, 16 frameshift mutations, 5 nonsense mutations, 3 splice site mutations, 1 in-frame deletion and 2 gross deletions. ${ }^{1-4}$ No evident genotype-phenotype correlation is apparent from comparison of patients with different mutations. ${ }^{1,5}$

\subsection{Analytical methods}

Various methods have been used for detection of point mutations (denaturing high-performance liquid chromatography, sequencing, and so on). MLPA (multiplex ligation-dependent probe amplification) kits for detection of deletions/duplications of one or more exons of the FGD1 gene are commercially available.

\subsection{Analytical validation}

This is undertaken by analysis of independent control samples for the presumed pathogenic mutation found in affected individuals, comparison to data base entries and journal data, and testing of other affected/unaffected relatives in the family to see if the mutation segregates only with disease and avoid possible polymorphisms (mainly in cases of novel missense mutations).

1.8 Estimated frequency of the disease (incidence at birth ('birth prevalence') or population prevalence)

A total of 29 molecularly proven cases have been published worldwide, ${ }^{1}$ but the number of clinically diagnosed cases is much larger. The majority of patients published before the advent of molecular tests have not been restudied for mutations. Experience in Leuven and in Manchester (JP Fryns and J Clayton-Smith: personal communications) indicates $2-3$ new patients with a proven mutation in the FGD1 gene per year, the same as for Angelman and PraderWilli syndrome, with a population prevalence of AAS probably lower or equal to $1 / 25000$.

1.9 If applicable, prevalence in the ethnic group of investigated persons

Not applicable. Almost all individuals in whom mutations have been sought are of Caucasian origin. However, clinical experience suggests that this condition occurs in many different ethnic groups.

\subsection{Diagnostic setting}

\begin{tabular}{lcc}
\hline & Yes & No \\
\hline A. (Differential) diagnostics & $\bigotimes$ & $\square$ \\
B. Predictive testing & $\square$ & $\square$ \\
C. Risk assessment in relatives & $\bigotimes$ & $\square$ \\
D. Prenatal & $\bigotimes$ & $\square$
\end{tabular}

Comment: Predictive testing - not applicable. As AAS is not a late onset disease and the signs are usually present in childhood, the genetic test, even in young children, are to be considered diagnostic and not predictive. Prenatal testing - see further (3.4) for considerations about the prenatal diagnosis.

\section{TEST CHARACTERISTICS}

\begin{tabular}{|c|c|c|c|c|}
\hline & \multicolumn{2}{|c|}{ Genotype or disease } & \multirow{2}{*}{$\begin{array}{l}\text { A: True positives } \\
\text { B: False positives }\end{array}$} & \multirow{2}{*}{$\begin{array}{l}\text { C: False negative } \\
\text { D: True negative }\end{array}$} \\
\hline & Present & Absent & & \\
\hline \multicolumn{5}{|l|}{ Test } \\
\hline Positive & $A$ & B & $\begin{array}{l}\text { Sensitivity: } \\
\text { Specificity: }\end{array}$ & $\begin{array}{l}A /(A+C) \\
D /(D+B)\end{array}$ \\
\hline Negative & C & $D$ & $\begin{array}{l}\text { Positive predictive value: } \\
\text { Negative predictive value: }\end{array}$ & $\begin{array}{l}A /(A+B) \\
D /(C+D)\end{array}$ \\
\hline
\end{tabular}

\footnotetext{
${ }_{1}^{1}$ Dipartimento dei Servizi, Medicina Molecolare, Azienda Ospedaliera Universitaria Senese, Siena, Italy; ${ }^{2}$ Genetica Medica, USL9, Ospedale 'Misericordia', Grosseto, Italy; ${ }^{3}$ Manchester Academic Health Sciences Centre, St Mary's Hospital, Manchester, UK; ${ }^{4}$ Departement Menselijke Erfelijkheid, Center for Human Genetics, University Hospital Leuven, Leuven, Belgium

^Correspondence: Dr A Orrico, Dipartimento dei Servizi, Medicina Molecolare, Azienda Ospedaliera Universitaria Senese, Policlinico ‘S. Maria alle Scotte', Viale Bracci 2, 53100 Siena, Italy.
}

Tel/Fax: +39 0577 586264. E-mail: a.orrico@ao-siena.toscana.it 
2.1 Analytical sensitivity (proportion of positive tests if the genotype is present) $100 \%$.

\subsection{Analytical specificity}

(proportion of negative tests if the genotype is not present) $100 \%$.

\subsection{Clinical sensitivity}

(proportion of positive tests if the disease is present)

Approximately 22\%. ${ }^{1}$ The clinical sensitivity can be dependent on variable factors such as age or family history. In such cases, a general statement should be given, even if a quantification can only be made case by case. Failure to detect a mutation in most patients referred for FGD1 analysis is likely to be largely attributable to the clinical and genetic heterogeneity of AAS, and the fact that the clinical features overlap with those of several other disorders (including Noonan's syndrome, SHORT syndrome, pseudohypoparathyroidism and Robinow syndrome). To reach the highest mutation detection rate, only affected individuals who fully met the classical diagnostic criteria should be considered for testing. ${ }^{1}$ This approach will, however, limit the probability of detecting a mutation in less typical patients, who may represent broader clinical subtypes of AAS. It is already acknowledged that some patients with pathogenic mutations do not have all the typical clinical features. ${ }^{6-8}$

\subsection{Clinical specificity}

(proportion of negative tests if the disease is not present)

The clinical specificity can be dependent on variable factors such as age or family history. In such cases, a general statement should be given, even if a quantification can only be made case by case.

$100 \%$.

\subsection{Positive clinical predictive value}

(life-time risk of developing the disease if the test is positive)

Not applicable; see comment to the point 1.10 'D' about predictive tests.

2.6 Negative clinical predictive value (probability not to develop the disease if the test is negative) Assume an increased risk based on family history for a non-affected person. Allelic and locus heterogeneity may need to be considered.

Index case in that family had been tested:

Not applicable (due to genetic heterogeneity).

Index case in that family had not been tested:

Not applicable.

\section{CLINICAL UTILITY}

3.1 (Differential) diagnosis: The tested person is clinically affected (To be answered if in 1.10 'A' was marked)

\subsubsection{Can a diagnosis be made other than through a genetic test?}

\begin{tabular}{lll}
\hline No & $\bigotimes($ continue with 3.1.4) & \\
Yes & $\square$ & $\square$ \\
& Clinically & $\square$ \\
& Imaging & $\square$ \\
& Endoscopy & $\square$ \\
& Biochemistry & $\square$ \\
& Electrophysiology & \\
& Other (please describe) \\
\hline
\end{tabular}

3.1.2 Describe the burden of alternative diagnostic methods to the patient

Not applicable.

3.1.3 How is the cost effectiveness of alternative diagnostic methods to be judged?

Not applicable.

3.1.4 Will disease management be influenced by the result of a genetic test?

No
Yes
Therapy (please $\quad \begin{aligned} & \text { There are no specific therapies for AAS. Some } \\ & \text { features (hypospadias, inguinal or umbilical hernias, } \\ & \text { cryptorchidism and unusually severe craniofacial } \\ & \text { features) may need surgical intervention. Radiologi- } \\ & \text { cal and orthopaedic surveys of the cervical spine } \\ & \text { should be carried out, as compression of nerve roots } \\ & \text { may be a consequence of cervical vertebral defects } \\ & \text { (hypoplasia of the first cervical vertebra, unfused } \\ & \text { posterior arch, synostosis, anomaly of the odon- } \\ & \text { toid). }{ }^{9} \text { The effect of growth hormone treatment on } \\ & \text { height gain has been reported only in preliminary } \\ & \text { studies and needs confirmation. }{ }^{10} \text { In the case of } \\ & \text { neurodevelopmental symptoms, generally mild } \\ & \text { learning problems and attention deficit and hyper- } \\ & \text { activity disorder, a neuropsychiatric opinion may be } \\ & \text { useful. }{ }^{11,12} \\ & \text { Due to the clinical and genetic heterogeneity, the } \\ & \text { identification of a FGD1 mutation in an AAS patient } \\ & \text { will not lead to a different prognosis, when compared } \\ & \text { with patients in whom a mutation was not found. } \\ & \text { However, the molecular test is essential to confirm } \\ & \text { clinical diagnosis and for accurate genetic counsel- } \\ & \text { ling of the families concerned. } \\ & \text { Multidisciplinary clinical follow-up (neuropsychia- } \\ & \text { trics,paediatrics, orthopaedic). A positive genetic } \\ & \text { test will impact on genetic counselling by permitting } \\ & \text { carrier detection, diagnosis in individuals with } \\ & \text { milder manifestations and the provision of an accu- } \\ & \text { rate recurrence risk for the families concerned. }\end{aligned}$

3.2 Predictive Setting: The tested person is clinically unaffected but carries an increased risk based on family history

(To be answered if in 1.10 'B' was marked)

\author{
3.2.1 Will the result of a genetic test influence lifestyle and \\ prevention? \\ If the test result is positive (please describe): \\ Not applicable. \\ If the test result is negative (please describe): \\ Not applicable.
}

3.2.2 Which options in view of lifestyle and prevention does a person at-risk have if no genetic test has been done (please describe)? Not applicable.

3.3 Genetic risk assessment in family members of a diseased person (To be answered if in 1.10 'C' was marked) 
3.3.1 Does the result of a genetic test resolve the genetic situation in that family?

A positive test (finding of a FGD1 mutation) will confirm the diagnosis of AAS and genetic counselling. It is useful, in particular, for carrier detection in females who may not manifest significant clinical signs. The assessment of recurrence risk for future pregnancies will be possible. A negative test will not completely rule out the possibility of AAS.

\subsubsection{Can a genetic test in the index patient save genetic or other tests in family members?}

Yes.

3.3.3 Does a positive genetic test result in the index patient enable a predictive test in a family member?

Not applicable; see comment to the point 1.10 ' $\mathrm{B}$ '.

\subsection{Prenatal diagnosis}

(To be answered if in 1.10 ' $\mathrm{D}$ ' was marked)

\subsubsection{Does a positive genetic test result in the index patient enable a prenatal diagnosis?}

Prenatal diagnosis for pregnancies at increased risk is possible when the disease-causing mutation in the family has been identified. However, in practice, prenatal testing is unlikely to be requested frequently, as even in male patients, physical signs can be mild and the broad variability of clinical expression in an individual family makes prediction of the phenotype difficult. ${ }^{13}$

\section{IF APPLICABLE, FURTHER CONSEQUENCES OF TESTING}

Please assume that the result of a genetic test has no immediate medical consequences. Is there any evidence that a genetic test is nevertheless useful for the patient or his/her relatives? (Please describe)

The result of an FGD1 genetic test may have no immediate medical consequences for the affected individual and their families, but having a positive molecular genetic diagnosis will influence genetic counselling and may influence reproductive decisions. It is likely that relatives will consider genetic counselling and carrier testing to assess their own risks.

\section{CONFLICT OF INTEREST}

The authors declare no conflict of interest.

\section{ACKNOWLEDGEMENTS}

This work was supported by EuroGentest, an EU-FP6 supported NoE, contract number 512148 (EuroGentest Unit 3: 'Clinical genetics, community genetics and public health', Workpackage 3.2) JC-S is supported by the Manchester NIHR Biomedical Research Centre.

1 Orrico A, Galli L, Faivre $L$ et al: Aarskog-Scott syndrome: clinical update and report of nine novel mutations of the FGD1 gene. Am J Med Genet A 2010; 152A: 313-318.

2 Schwartz CE, Gillessen-Kaesbach G, May M et al.: Two novel mutations confirm FDG1 is responsible for the Aarskog syndrome. Eur J Hum Genet 2000; 8: 869-874.

3 Bedoyan JK, Friez MJ, Dupont B, Ahmad A: First case of deletion of the faciogenital dysplasia 1 (FGD1) gene in a patient with Aarskog-Scott syndrome. Eur J Med Genet 2009; 52: 262-264.

4 Baldi M, Mural, De Cassan P et al.: Sindrome di Aarskog: nuove mutazioni del gene FGD1. XII Congresso SIGU.; Abstract book: poster 105. Torino 8-10 Novembre 2009.

5 Orrico A, Galli L, Cavaliere ML et al.: Phenotypic and molecular characterisation of the Aarskog syndrome: a survey of the clinical variability in light of $F D G 1$ mutation analysis in 46 patients. Eur J Hum Genet 2004; 12: 16-23.

6 Lebel RR, May M, Pouls S, Lubs HA, Stevenson RE, Schwartz CE: Non-syndromic $\mathrm{X}$-linked mental retardation associated with a missense mutation (P312 L) in the FGD1 gene. Clin Genet 2002; 61: 139-145.

7 Bottani A, Orrico A, Galli L et al.: Unilateral focal polymicrogyria in a patient with classical Aarskog-Scott syndrome due to a novel missense mutation in an evolutionary conserved RhoGEF domain of the faciogenital dysplasia gene FGD1. Am J Med Genet $A$ 2007; 143A: 2334-2338.

8 Orrico A, Galli L, Obregón MG, de Castro Perez MF, Falciani M, Sorrentino V: Unusually severe expression of craniofacial features in Aarskog-Scott syndrome due to a novel truncating mutation of the FDG1 gene. Am J Med Genet A 2007; 143: 58-63.

9 Fryns JP: Aarskog syndrome: the changing phenotype with age. Am J Med Genet 1992; 43: 420-427.

10 Satoh M, Yokoya S: Anabolic steroid and gonadotropin releasing hormone analog combined treatment increased pubertal height gain and adult height in two children who entered puberty with short stature. J Pediatr Endocrinol Metab 2006; 19: $1125-1131$.

11 Orrico A, Galli L, Buoni S et al: Attention-deficit/hyperactivity disorder (ADHD) and variable clinical expression of Aarskog-Scott syndrome due to a novel FGD1 gene mutation (R408Q). Am J Med Genet A 2005; 135: 99-102.

12 Kaname T, Yanagi K, Okamoto N, Naritomi K: Neurobehavioral disorders in patients with Aarskog-Scott syndrome affected by novel FGD1 mutations. Am J Med Genet $A$ 2006; 140: 1331-1332.

13 Shalev SA, Chervinski E, Weiner E, Mazor G, Friez MJ, Schwartz CE: Clinical variation of Aarskog syndrome in a large family with 2189delA in the FGD1 gene. Am J Med Genet A 2006; 140: 162-165. 